\title{
INDEKS LABILITAS UDARA UNTUK MEMPREDIKSI KEJADIAN BADAI GUNTUR PADA PUNCAK MUSIM HUJAN TAHUN 2016
}

\section{The Use of Atmospheric Instability Indices to Predict Thunderstorm Event on Peak Wet Season Condition in 2016}

\author{
Nyayu Fatimah Zahroh ${ }^{1)^{*}}$, Ni Wayan Srimani Puspa Dewi ${ }^{2)}$, Dini Harsanti ${ }^{3)}$ \\ ${ }^{1,3)}$ Balai Besar Teknologi Modifikasi Cuaca (BB-TMC) - BPPT, Gedung Ir. Mohammad Soebagio, \\ GEOSTECH. Kawasan Puspiptek, Serpong, Tangerang Selatan 15314. \\ ${ }^{2)}$ Program Studi Klimatologi Terapan, Institut Pertanian Bogor \\ *E-mail : nyayu.fatimah@bppt.go.id
}

\begin{abstract}
Intisari
Prediksi kejadian badai guntur menjadi perhatian masyarakat luas karena biasanya disertai dengan curah hujan yang tinggi, terutama untuk wilayah rawan banjir seperti provinsi DKI Jakarta. Penelitian ini bertujuan untuk analisis potensi hujan disertai badai guntur dengan menggunakan data radiosonde, analisis indeks labilitas berdasarkan parameter yang didapat dari radiometer dan analisis tren indeks labilitas 6 jam sebelum kejadian hujan. Ada beberapa tanggal yang menjadi perhatian yaitu hari dimana kejadian hujan disertai badai guntur tinggi pada tanggal 28-31 Januari 2016 serta tanggal 14 Februari 2016 dan kejadian hujan tanpa badai guntur pada tanggal 3-4 Februari 2016. Hasil penelitian menunjukan bahwa terdapat perbedaan hasil sounding sebelum hujan dan pada saat hujan. Hasil sounding sebelum kejadian hujan memiliki labilitas moderat dan sounding pada saat kejadian hujan/badai guntur memiliki labilitas kuat. Selain itu, data dari radiometer menunjukan perbedaan signifikan antara perubahan tren indeks labilitas pada 6 jam sebelum kejadian hujan yang disertai badai guntur, dan pada kejadian hujan tanpa badai guntur.
\end{abstract}

Kata Kunci : Badai Guntur, Radiosonde, Radiometer, Indeks Labilitas, Banjir DKI Jakarta.

\begin{abstract}
Predictions of a thunderstorm event become an attention for wide society because it is usually accompanied by heavy rainfall, especially for the flood prone area like the province of Jakarta. The objective of this study is to analyze the potential of rain with thunderstorms using radiosonde data, to analyze the instability indices based on parameters that obtained from Radiometer, and to analyze the trends of instability indices in 6 hours before the storm event. There are a few dates that become attention, the day where rain events with thunderstorms is high which is on January 28th-31st, 2016 and February 14th, 2016, and the rain event without thunderstorm on February 3rd-4th, 2016. The results showed that there are different sounding results before rain event and when it rains. The sounding result before rain event has moderate lability and sounding result when rain event has strong lability. In addition, the data from the radiometer showed a significant difference between the predicted 6 hours prior to the event of rain with a thunderstorm and rain without thunderstorm events.
\end{abstract}

Keywords : Thunderstorm, Radiosonde, Radiometer, Instability Indices, Jakarta Flood.

\section{PENDAHULUAN}

Badai guntur (thunderstorm) merupakan badai yang terdiri atas petir dan guntur yang dihasilkan dari beberapa gugusan awan cumulonimbus. Pada umumnya, badai guntur terbentuk ketika udara hangat dan lembap naik pada kondisi lingkungan yang tidak stabil bersyarat, yaitu dimana udara dingin dan kering menindih udara permukaan hangat dan lembap. Semakin hangat suatu parsel udara (dibandingkan dengan udara sekitarnya), maka semakin besar gaya apung dan aktivitas konveksi (Ahrens, 2009).

Received : 23 February 2017
Pembentukan badai guntur biasanya disertai dengan turbulensi, petir, pembentukan es, pengurangan jarak pandang, angin kencang dan hujan lebat (Mayangwulan et al., 2011).

Salah satu cara untuk memprediksi kejadian badai guntur adalah melalui analisis kondisi udara atas dari hasil sounding. Dari rekaman data sounding akan menghasilkan indeks-indeks labilitas atmosfer salah satunya untuk menduga kejadian badai guntur. Indeksindeks tersebut salah satunya adalah Lifted Index, Showalter Index, K-Index, Total-Totals Index, dan SWEAT Index yang secara langsung dapat diketahui dari data sounding dengan 
menggunakan perangkat lunak RAOB (Rawindsonde Observation).

Dampak dari badai guntur dapat mengganggu bahkan merugikan aktivitas manusia salah satunya dalam aktivitas penerbangan. Mayangwulan et al. (2011) menyatakan bahwa resiko buruk badai guntur terhadap aktivitas penerbangan dapat dikurangi dengan memprediksi potensi terjadinya badai guntur. Oleh karena itu, hampir disetiap bandara selalu diluncurkan radiosonde untuk memprediksi terjadinya badai guntur yang dapat membahayakan penerbangan sehingga dapat menurunkan potensi terjadinya kecelakaan. Selain untuk aktivitas penerbangan, mengetahui potensi badai guntur juga dapat digunakan untuk memprediksi kejadian banjir karena curah hujan yang lebat yang dihasilkan dari badai guntur.

Penelitian ini bertujuan untuk menganalisis potensi hujan disertai badai guntur dengan menggunakan data radiosonde dan menganalisis indeks labilitas serta menganalisis tren indeks labilitas 6 jam sebelum kejadian hujan dari data Radiometer.

\section{METODE}

Data yang digunakan dalam penelitian ini berasal dari kegiatan pengamatan atmosfer secara intensif (Intensive Observation Period; IOP) yang dilaksanakan oleh BB-TMC BPPT dan BMKG. Data tersebut terdiri atas data Radiosonde, data curah hujan dan jumlah kejadian badai guntur yang diperoleh dari BMKG Dramaga Bogor, dan data sounding dari Radiometer yang diletakan di wilayah Stasiun BMKG Dramaga. Dari data-data di atas, kemudian dicari hubungannya berdasarkan indeks labilitas atmosfer dari data sounding dan radiometer.

Indeks labilitas atmosfer digunakan untuk melihat potensi kejadian badai guntur di wilayah tersebut. Indeks labilitas atmosfer yang digunakan adalah K-Index, Total-Totals Index, dan SWEAT. Kegiatan ini dilaksanakan selama periode puncak musim hujan yang berlangsung selama 30 hari, sejak tanggal 18 Januari hingga 16 Februari 2016. Tujuan dilaksanakannya IOP adalah untuk mengetahui cuaca ekstrim penyebab banjir di wilayah DKI Jakarta dan sekitarnya.

\subsection{Radiosonde}

Radiosonde merupakan suatu alat yang dapat mengukur distribusi temperatur, kelembapan, dan tekanan dari permukaan hingga mencapai ketinggian $30 \mathrm{~km}$. Kini, radiosonde sudah bisa mengukur arah dan kecepatan angin yang dinamakan rawinsonde. Radiosonde sering digunakan di bandara bandara untuk mengetahui profil vertikal kondisi cuaca, biasanya diluncurkan minimal dua kali sehari. Bukan hanya untuk keperluan transportasi udara saja, namun pelepasan radiosonde juga berguna untuk mengidentifikasi kondisi meteorologi ke depan seperti untuk memprediksi kejadian badai guntur.

Pengamatan radiosonde dilakukan dalam kegiatan Intensive Observation Period (IOP) untuk mengetahui kondisi profil udara secara vertikal. Dengan begitu, prediksi cuaca dapat dilakukan untuk beberapa jam setelah peluncuran radiosonde. Dalam IOP dilakukan empat kali peluncuran radiosonde dalam satu hari di Stasiun BMKG Dramaga yaitu pada jam 0 , $6,12,18$ UTC. Dengan pengamatan yang lebih banyak dari biasanya (lebih dari dua kali sehari) maka analisis dapat dilakukan lebih mendalam.

Stabilitas atmosfer yang digunakan dalam analisis kejadian badai guntur adalah K-Index, Total-Totals Index (TT) dan SWEAT. Masingmasing indeks tersebut diperoleh dari data radiosonde yang dijalankan menggunakan aplikasi RAOB. Indeks-indeks ini dipilih karena telah disesuaikan kriteria indeksnya terhadap kejadian badai guntur di wilayah Indonesia (Budiarti et al, 2012; Meilani et al, 2014; Novianti et al, 2015; Ratnam et al, 2013; Tajbakhsh et al, 2012).

\subsection{Radiometer}

Radiometer merupakan suatu alat yang mengukur temperatur udara, kelembapan udara, serta kandungan air di udara. Kegunaan radiometer hampir sama dengan pengukuran radiosonde, dengan keunggulan dan kelemahan di masing-masing alat. Beberapa keunggulan radiometer dibandingkan dengan radiosonde adalah radiometer bersifat statis, pengukuran kontinu, dan biaya operasional lebih murah. Sedangkan kekurangan dari radiometer adalah ketinggian hanya sampai $10 \mathrm{~km}$ dan resolusi yang kurang baik pada lapisan di atas $7 \mathrm{~km}$.

Keunggulan yang dimiliki oleh radiometer dapat dimanfaatkan untuk menutupi kekurangan dari pengukuran menggunakan radiosonde, salah satunya adalah pengukuran yang kontinu. Peluncuran radiosonde pada kegiatan IOP ini dilakukan empat kali dalam sehari sedangkan pengukuran radiometer terus berjalan selama alat masih dalam kondisi baik dan suplai listrik terpenuhi. Karena memiliki kegunaan yang mirip dengan radiosonde maka data dari radiometer dapat digunakan untuk prediksi kejadian badai guntur melalui indeks stabilitas atmosfer yang dihasilkan. Selain itu, penelitian yang dilakukan oleh Athoillah et al. (2016) menunjukan bahwa data dari radiosonde dan radiometer memiliki kecocokan terutama pada kejadian hujan ekstrem.

Menurut Ferdiansyah (2012) indeks stabilitas atmosfer dapat menjadi prediktor yang baik untuk kejadian hujan pada 6 jam sebelum kejadian. Dengan menggunakan radiometer, 
prediksi kejadian hujan dan badai guntur dapat dilakukan dengan tepat karena data yang dihasilkan radiometer berupa data kontinyu atau realtime. Berbeda dengan radiosonde yang datanya tidak langsung diperoleh dan peluncurannya pun tidak bisa setiap saat (Mattioli et al., 2008; Chan, 2009).

\subsection{K-Index}

K-Indeks (KI) merupakan suatu ukuran potensi badai akibat gerak konvektif yang diukur berdasarkan selang suhu vertikal dan kelembapan atmosfer. Nilai KI dihitung berdasarkan nilai suhu pada lapisan 850, 700, dan 500 mb serta nilai suhu titik embun pada lapisan 850 dan $700 \mathrm{mb}$. Berikut adalah persamaan $\mathrm{KI}$

$K I=T_{850}-T_{500}+T d_{850}-\left(T_{700}-T d_{700}\right)$

Dimana $T$ merupakan suhu dan $T d$ merupakan suhu titik embun. Semakin besar perbedaan suhu antara lapisan 850 dan 500 mb, maka semakin tinggi kelembapannya dan semakin besar nilai KI-nya. Jika nilai KI semakin besar maka semakin berpotensi terjadinya konveksi.

Jika dilihat dari pola diurnalnya, nilai $\mathrm{K}$ indeks semakin siang nilainya semakin tinggi karena kondisi atmosfer yang semakin tidak stabil (Ratnam et al., 2013).

\subsection{Total-Totals Index (TT)}

Total-Totals Index (TT) adalah salah satu indeks yang dapat menentukan proses konveksi yang merupakan gabungan dari indeks vertical totals dan cross totals. Vertical totals merupakan selisih antara suhu lingkungan pada lapisan 850 $\mathrm{mb}$ dan $500 \mathrm{mb}$ sedangkan cross totals merupakan selisih antara suhu titik embun pada lapisan $850 \mathrm{mb}$ dengan suhu lingkungan pada lapisan $500 \mathrm{mb}$. Persamaan TT ditulis sebagai berikut:

$T T=\left(T_{850}-T_{500}\right)+\left(T d_{850}-T_{500}\right)$

Dimana $T$ merupakan suhu lingkungan dan Td merupakan suhu titik embun. Semakin tinggi suhu dan kelembapan pada lapisan $850 \mathrm{mb}$ serta semakin rendah suhu pada lapisan 500 mb maka semakin besar nilai TT atau kondisi atmosfer semakin tidak stabil.

\subsection{SWEAT}

SWEAT (Severe Weather Threat Index) merupakan indeks untuk melihat potensi cuaca buruk dengan tetap memperhitungkan mekanisme lain yang mempengaruhi terjadinya cuaca buruk

$$
\begin{aligned}
\text { SWEAT }= & 12 T d_{850}+20(T T-49)+2 f_{850} \\
& +f_{500}+125(s+0.2)
\end{aligned}
$$

Dimana Td merupakan suhu titik embun, $T T$ total-totals index, $f$ kecepatan angin (knots), dan $s$ sin arah angin pada lapisan $500 \mathrm{mb}$ dan $850 \mathrm{mb}$.

Studi mengenai indeks labilitas udara sudah banyak dilakukan salah satunya oleh Budiarti et al (2012) yang mengkaji ulang interval indeks stabilitas atmosfer yang lebih cocok untuk wilayah lintang rendah. Hal tersebut karena interval indeks-indeks yang sudah ada merupakan kajian di wilayah subtropis sehingga perlu dikaji lebih lanjut untuk interval indeks yang lebih cocok untuk wilayah tropis. Indeks stabilitas yang dikaji adalah Total-Totals Index, K-Index, dan SWEAT. Berikut adalah hasil dari kajian tersebut.

Tabel 1. Interval Indeks Stabilitas Atmosfer untuk Wilayah Tropis (Budiarti et al., 2012).

\begin{tabular}{|l|l|l|l|}
\hline Indeks & Lemah & Moderat & Kuat \\
\hline TT Index & $<42$ & $42-46$ & $>46$ \\
\hline K Index & $<29$ & $29-37$ & $>37$ \\
\hline SWEAT & $<135$ & $135-239$ & $>239$ \\
\hline
\end{tabular}

\section{HASIL DAN PEMBAHASAN}

\subsection{Potensi Badai Guntur Menggunakan Sounding}

Secara berturut-turut curah hujan yang tercatat di Stasiun BMKG Dramaga pada tanggal 28-31 Januari 2016 adalah $48 \mathrm{~mm}, 18 \mathrm{~mm}, 26$ $\mathrm{mm}$, dan 30,7 mm. Sedangkan untuk jumlah badai guntur yang tercatat pada tanggal tersebut secara berturut-turut sebanyak 126, 572, 423, dan 633. Hasil prediksi badai guntur menggunakan radiosonde pada tanggal 28-31 Januari 2016 dapat dilihat pada Gambar 1.

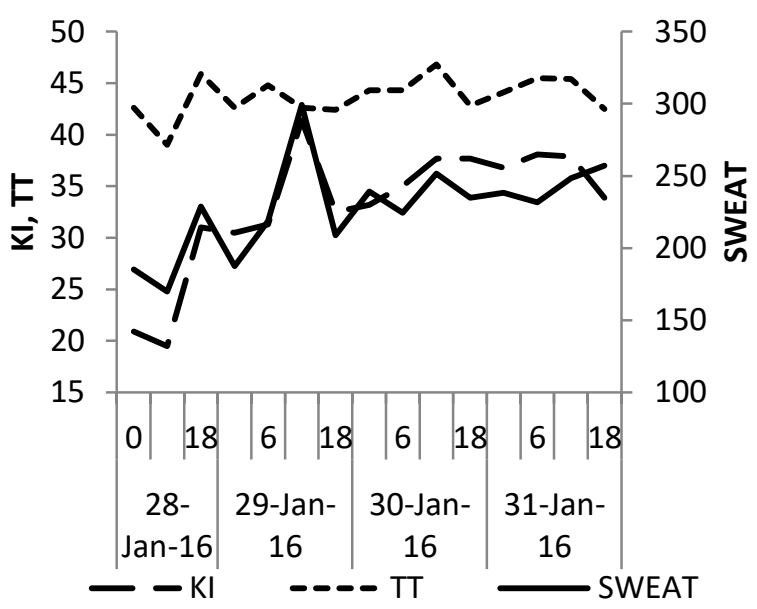

Gambar 1. Indeks stabilitas atmosfer pada tanggal 28-31 Januari 2016 dari data Radiosonde.

Berdasarkan Gambar 1 terlihat bahwa pada jam 12 UTC tanggal 29 dan 31 Januari 2016 terdapat potensi terjadinya badai guntur sedang hingga kuat. Kemudian potensi terjadinya 
badai guntur kuat juga terlihat pada hasil sounding pada tanggal 30 Januari 2016 jam 12 UTC. Pada jam tersebut kondisi cuaca sedang turun hujan yang disertai dengan badai guntur. Sedangkan hasil sounding pada jam 6 UTC atau sebelum kejadian hujan disertai badai guntur menunjukan potensi badai guntur moderat/sedang. Begitu pula pada tanggal 29 Januari 2016 dimana kejadian hujan sekitar jam 12 UTC. Jika dilihat dari hasil sounding sebelum kejadian hujan/badai guntur yaitu jam 6 UTC maka hasil sounding menunjukan potensi terjadinya badai guntur sedang.

Salah satu kejadian hujan yang berpengaruh terhadap kejadian banjir Jakarta adalah kejadian hujan pada tanggal 14 Februari 2016. Kejadian hujan tersebut telah menggenangi beberapa wilayah DKI Jakarta setinggi $50 \mathrm{~cm}$ yaitu di beberapa wilayah di Jakarta Selatan dan di Jakarta Barat, menggenangi 6 Kecamatan, 6 Kelurahan dan 11 RW (BPBD DKI Jakarta).

Curah hujan yang terjadi pada tanggal 14 Februari 2016 tercatat di Stasiun BMKG Dramaga Bogor sebesar $39 \mathrm{~mm}$ dengan badai guntur sebanyak 351. Potensi badai guntur kuat juga terlihat dari hasil sounding pada tanggal 14 Februari 2016 jam 12 UTC dimana pada waktu tersebut sedang terjadi hujan/badai guntur (Gambar 2). Jika dilihat pada data sounding sebelum kejadian hujan/badai guntur, maka potensi menunjukkan terjadinya badai guntur sedang.

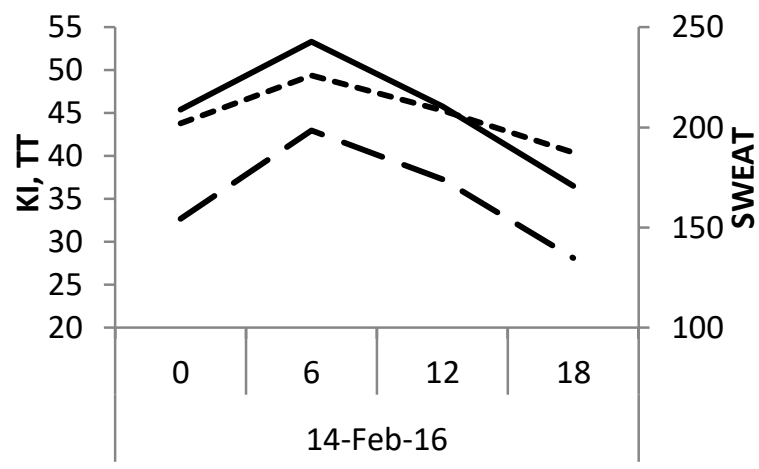

$$
\text { - } \mathrm{KI} \quad--\mathrm{TT} \longrightarrow \text { SWEAT }
$$

Gambar 2. Indeks stabilitas atmosfer pada tanggal 14 Februari 2016 dari data Radiosonde.

Perlu dilihat pula indeks stabilitas atmosfer pada kondisi tidak ada badai guntur, seperti pada tanggal 3-4 Februari 2016 secara berturut-turut memiliki curah hujan $14.6 \mathrm{~mm}$ dan $3.8 \mathrm{~mm}$ tanpa kejadian badai guntur (Gambar 3). Jika dilihat dari sensor hujan yang ada di radiometer, kejadian hujan pada tanggal 3 Februari terjadi sekitar jam 12 UTC. Itulah penyebab nilai indeks stabilitas cenderung tinggi pada jam tersebut. Namun, sounding jam 6 UTC sebelum kejadian hujan pada tanggal 3 Februari menunjukan nilai indeks yang termasuk kategori badai guntur sedang. Begitu pula dengan kejadian hujan tanggal 4 Februari, potensi badai guntur lemah pada jam 0 UTC, lalu cenderung kuat pada jam 6 UTC kecuali indeks Total-Totals yang cenderung lemah.

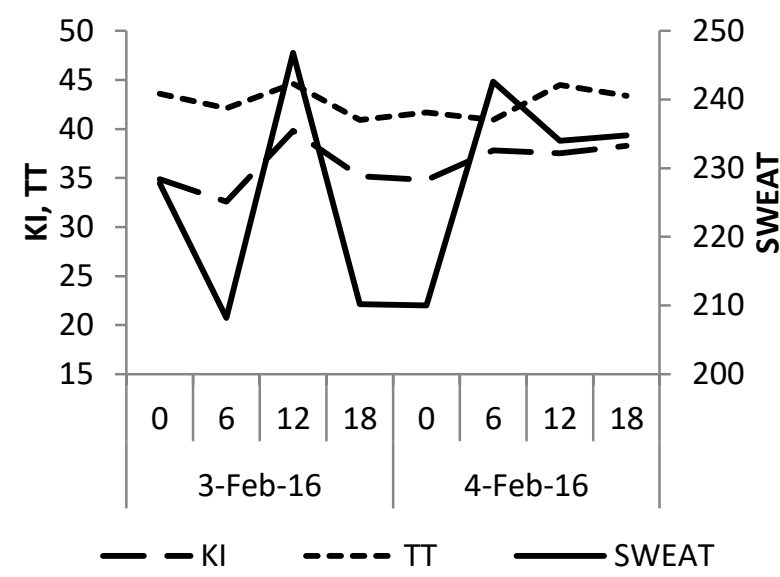

Gambar 3. Indeks stabilitas atmosfer pada tanggal 3-4 Februari 2016 dari data Radiosonde.

Dari hasil sounding yang dilakukan di beberapa kejadian hujan menunjukan bahwa indeks stabilitas atmosfer cenderung labil kuat pada saat kejadian hujan disertai badai guntur. Indeks stabilitas juga cederung labil moderat pada hasil sounding sebelum terjadi badai guntur. Hal ini menunjukkan bahwa secara umum kejadian hujan/badai guntur dapat terjadi beberapa jam kemudian dengan hasil sounding yang menunjukan labilitas moderat/sedang.

Ilhamsyah (2012) menunjukkan hasil penelitian bahwa kondisi tidak stabil pada lapisan terbawah troposfer yang identik dengan laju penurunan adiabatik kering dimana paket udara naik karena pemanasan permukaan, sementara setelah paket udara mengalami kondisi jenuh pada LCL (titik jenuh) terjadi laju adiabatik basah, yang mempunyai arti bahwa bila paket udara ini terus naik melalui troposfer maka berpeluang terhadap terjadinya badai guntur. Selain itu, terjadinya badai petir juga dipicu oleh ketidakstabilan konvektif yang ditandai dengan terbentuknya lapisan inversi.

\subsection{Potensi Badai Guntur 6 Jam Sebelum Kejadian Hujan Menggunakan Radiometer}

Dari data observasi di stasiun BMKG Dramaga diketahui bahwa pada tanggal 28-31 Januari 2016 memiliki kejadian badai guntur dan curah hujan yang cukup tinggi. Di Gambar 4 dapat dilihat garis waktu KI, TT, dan SWEAT pada tanggal 28 dan 29 Januari 2016. Wilayah yang diarsir abu merupakan waktu dimana kejadian hujan berlangsung, sedangkan yang diarsir kuning merupakan prediksi 6 jam sebelum kejadian badai guntur. 


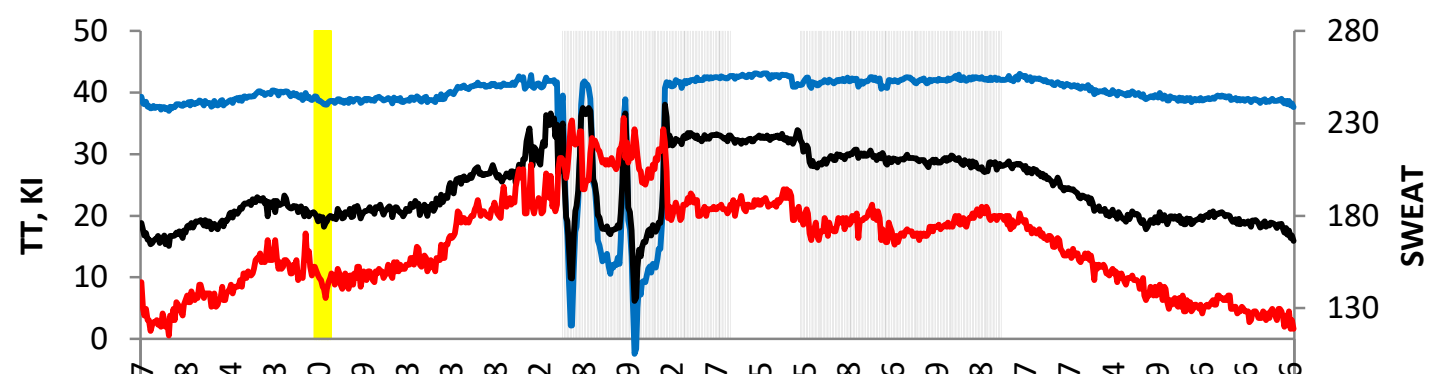

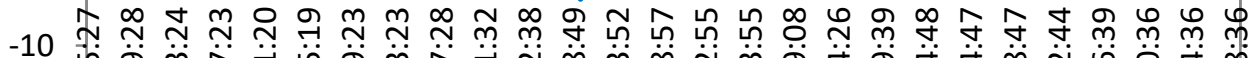
䒘 80

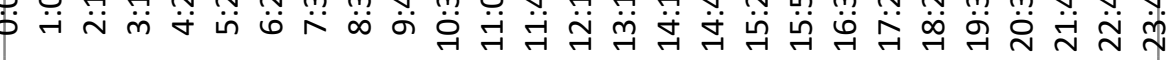
28-Jan-16

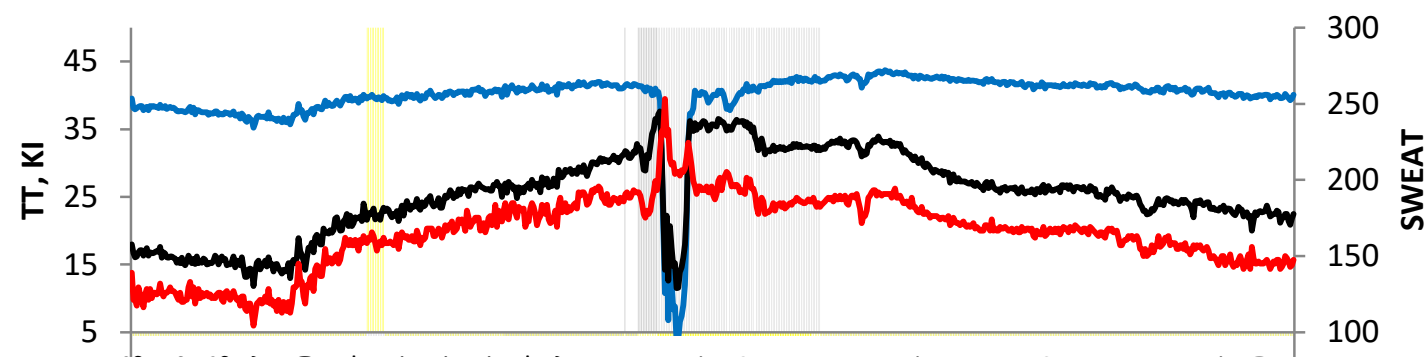

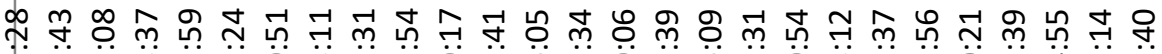

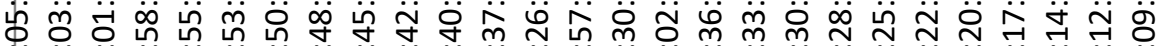

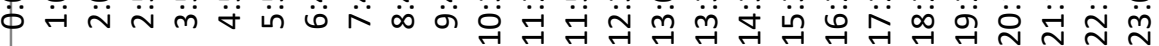
29-Jan-16
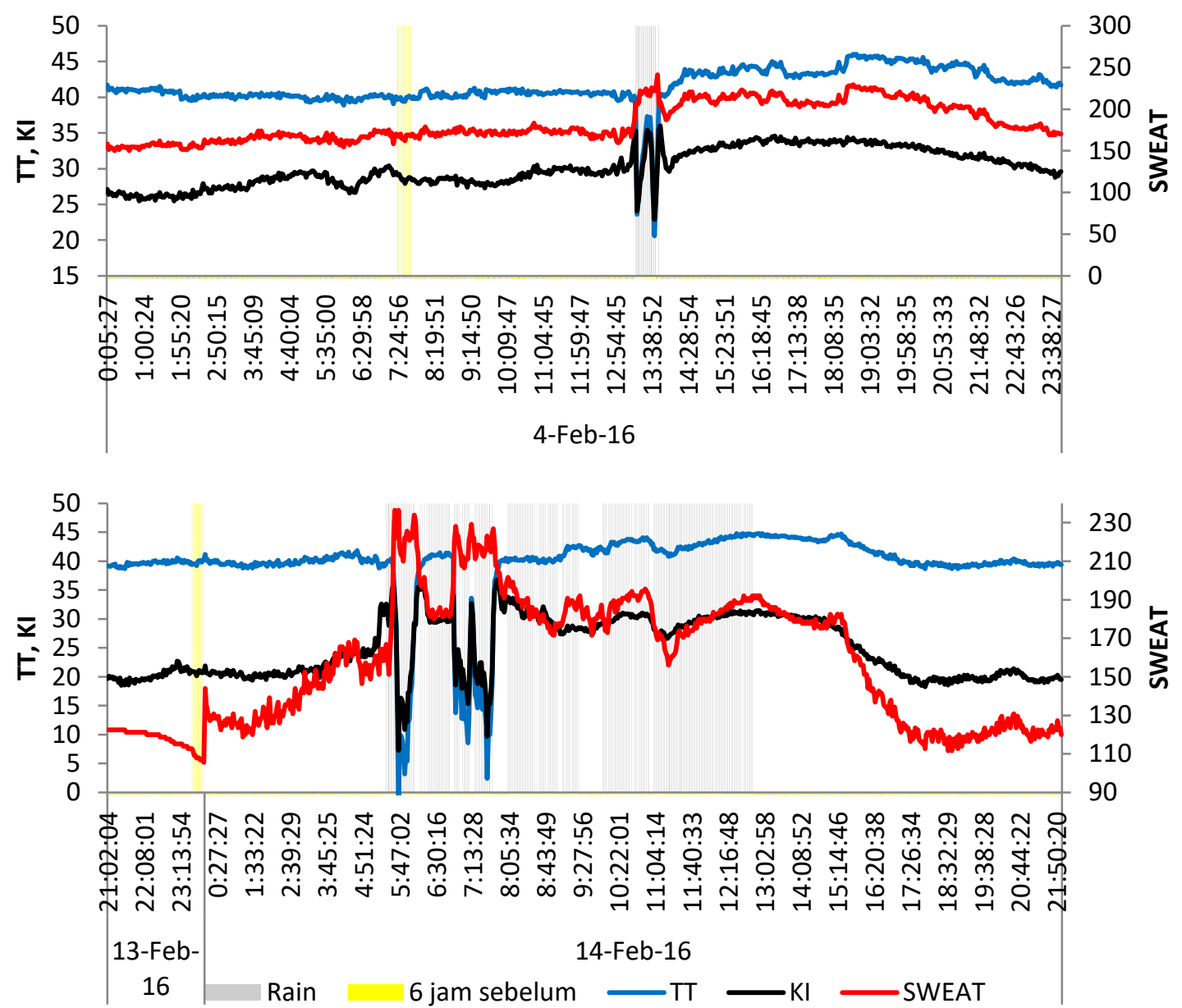

Gambar 4. Garis waktu indeks labilitas pada saat kejadian hujan tanggal 28-29 Januari, 4 Februari dan 14 Februari 2016 dari data Radiometer. 
Indeks labilitas yang dihasilkan oleh data radiometer 6 jam sebelum hujan pada tanggal 28 Januari 2016 menunjukan indeks SWEAT moderat, dan labilitas lemah untuk indeks $\mathrm{KI}$ dan TT. Pada 3 jam sebelum kejadian hujan, indeks $\mathrm{KI}$ menjadi moderat dan menjadi kuat pada 10 menit sebelum kejadian hujan disertai badai guntur, sedangkan indeks TT berubah menjadi labilitas sedang satu jam sebelum kejadian hujan disertai badai guntur. Pada tanggal 29 Januari 2016, sejak 6 jam sebelum kejadian, indeks SWEAT moderat dan indeks TT dengan labilitas lemah. Sedangkan untuk indeks KI, pada 6 jam sebelum kejadian memiliki labilitas lemah dan meningkat menjadi labilitas moderat pada 4 jam sebelum kejadian.

Berbeda dengan kejadian hujan pada tanggal 28 dan 29 Januari 2016, pada tanggal 14 Februari 2016 indeks labilitas 6 jam sebelum kejadian menunjukan labilitas lemah. Kemudian indeks meningkat menjadi labilitas sedang pada 3 jam sebelum kejadian hujan untuk indeks SWEAT dan 30 menit sebelum kejadian untuk indeks KI. Indeks labilitas pada tanggal tersebut menunjukan bahwa prediksi 6 jam tidak berlaku karena menunjukan kondisi atmosfer yang cenderung stabil, lalu 3 jam kemudian baru menunjukan labilitas yang sedang.

Jika dibandingkan dengan indeks labilitas pada tanggal 4 Februari 2016 dimana terdapat kejadian hujan tanpa badai guntur, maka indeks menunjukan perubahan yang sedikit sejak 6 jam sebelum kejadian yaitu labilitas moderat untuk KI dan SWEAT serta labilitas lemah untuk indeks TT. Perubahan indeks labilitas kejadian hujan pada tanggal-tanggal tersebut dapat dilihat dari tren yang terbentuk sejak 6 jam sebelum kejadian hingga sesaat sebelum kejadian hujan. Dari tabel 2 dapat dilihat bahwa terdapat kenaikan tren indeks labilitas terhadap waktu pada kejadian hujan disertai badai guntur yaitu pada tanggal 28-29 Januari dan 14 Februari 2016.

Tabel 2. Tren Indeks Labilitas Terhadap Waktu dari 6 Jam Sebelum Kejadian Hingga Beberapa Menit Sebelum Kejadian Hujan.

\begin{tabular}{|c|c|c|c|}
\hline Tanggal & TT & $\mathrm{KI}$ & SWEAT \\
\hline \multirow{2}{*}{ 28 Jan } & $\begin{array}{c}\mathrm{Y}=0.02 \mathrm{x}+ \\
38.135\end{array}$ & $\begin{array}{c}\mathrm{Y}=0.085 \mathrm{x} \\
+17.318\end{array}$ & $\begin{array}{c}\mathrm{Y}=0.387 \mathrm{x}+ \\
135.11\end{array}$ \\
\hline \multirow{2}{*}{ 29 Jan } & $\begin{array}{c}\mathrm{Y}=0.015 \mathrm{x} \\
+39.453\end{array}$ & $\begin{array}{c}\mathrm{Y}=0.056 \mathrm{x} \\
+21.93\end{array}$ & $\begin{array}{c}\mathrm{Y}=0.213 \mathrm{x}+ \\
157.38\end{array}$ \\
\hline \multirow{2}{*}{ 4 Feb } & $\begin{array}{c}\mathrm{Y}=0.002 \mathrm{x} \\
+40.325\end{array}$ & $\begin{array}{c}\mathrm{Y}=0.015 \mathrm{x} \\
+27.771\end{array}$ & $\begin{array}{c}\mathrm{Y}=0.007+ \\
171.31\end{array}$ \\
\hline \multirow{2}{*}{ 14 Feb } & $\begin{array}{c}\mathrm{Y}=0.006 \mathrm{x} \\
+39.43\end{array}$ & $\begin{array}{c}\mathrm{Y}=0.037 \mathrm{x} \\
+18.856\end{array}$ & $\begin{array}{c}\mathrm{Y}=0.317 \mathrm{x}+ \\
113.19\end{array}$ \\
\hline
\end{tabular}

Pada tanggal 28 Januari 2016 menunjukkan kenaikan tren yang cukup curam terhadap waktu pada indeks TT, KI, dan SWEAT.
Hal ini menunjukan bahwa terdapat perubahan yang signifikan sejak 6 jam sebelum kejadian hingga beberapa menit sebelum kejadian.

Begitu pula pada tanggal 14 Februari 2016, tren indeks $\mathrm{KI}$ dan SWEAT meningkat sejak 6 jam sebelum kejadian hujan hingga sesaat sebelum kejadian hujan yaitu dengan tren $y=0.037 x+18.856$ untuk KI dan $y=0.317 x+113.19$ untuk SWEAT. Namun untuk tren indeks TT cukup landai, sehingga kenaikan indeks labilitas tidak terlalu signifikan seperti pada tanggal 28-29 Januari 2016.

Berbeda dengan kejadian hujan tanpa badai guntur yang terjadi pada tanggal 4 Februari 2016 yang memiliki tren yang cukup landai pada indeks TT, KI, dan SWEAT, secara berturut-turut, $y=0.002 x+40.325, \quad y=0.015 x+27.771, \quad$ dan $y=0.007+171.31$. Hal ini menunjukan perubahan yang tidak signifikan untuk indeks labilitas kejadian hujan tanpa badai guntur.

\section{KESIMPULAN}

Jika dilihat pada sounding radiosonde sebelum terjadi hujan/badai guntur maka potensi labilitas atmosfernya cenderung moderat, sedangkan potensinya semakin tinggi ketika sounding dilakukan pada saat terjadi hujan dan badai guntur. Kondisi atmosfer yang labil ketika terjadi hujan/badai guntur membuat hasil sounding menunjukan indeks labilitas tinggi.

Begitu pula dengan radiometer, indeks labilitas yang dihasilkan menunjukan adanya peningkatan dari 6 jam sebelum kejadian hujan hingga sesaat sebelum kejadian hujan. Namun, terdapat tren yang berbeda antara kejadian hujan dengan badai guntur dan kejadian hujan tanpa badai guntur. Kejadian hujan disertai badai guntur memiliki kenaikan tren indeks labilitas yang signifikan dibandingkan dengan kejadian hujan tanpa badai guntur.

Karena sedikitnya kejadian hujan yang terobservasi selama kegiatan ini, maka perlu dilakukan observasi tingkat lanjut sehingga dapat dilakukan analisis lebih mendalam mengenai indeks labilitas yang dihasilkan dari data radiometer.

Penelitian ini berbeda dengan penelitian yang dilakukan oleh Ferdiansyah (2012). Meskipun sama-sama menganalisis potensi badai guntur pada 6 jam sebelum kejadian hujan, tetapi penelitian ini lebih presisi soal waktu karena menggunakan radiometer dimana data yang dihasilkan memiliki interval waktu yang lebih rapat. Selain itu, indeks labilitas yang digunakan juga berbeda kecuali KI.

\section{DAFTAR PUSTAKA}

Ahrens, C.D. (2009). Meteorology Today: An Introduction to Weather, Climate, and Environment. Belmont. Brooks/Cole. 
Athoillah, I., Dewi, S., Renggono, F. (2016). Perbandingan Pengukuran Radiometer dan Radiosonde pada Musim Hujan di Dramaga Bogor. Jurnal Sains \& Teknologi Modifikasi Cuaca, 17(2), 75-82.

BPBD DKI Jakarta. (2016). Peta Daerah Banjir Provinsi DKI Jakarta Tanggal 14 Februari $2016 \quad$ Pukul 18:00 WIB. (http://gis.bpbd.jakarta.go.id/documents).

Budiarti, M., Muslim, M., Ilhamsyah, Y. (2012). Studi Indeks Stabilitas Udara Terhadap Prediksi Kejadian Badai Guntur (Thunderstorm) di Wilayah Stasiun Meteorologi Cengkareng Banten. Jurnal Meteorologi dan Geofisika, 13(2), 111-117.

Chan, P.W. (2009). Performance and Application of a Multi-Wavelength, Ground-Based Microwave Radiometer in Intense Convective Weather. Meteorologische Zeitschrift, 18(3), 253-265. doi: 10.1127/0941-2948/2009/0375

Ferdiansyah, A. (2012). Potensi Parameter Keluaran RAOB (Rawinsonde Observation Programs) Sebagai Indikator Kunci dalam Analisis Curah Hujan. Skripsi. FMIPA, Institut Pertanian Bogor.

Mattioli, V., Westwater, E.R., Cimini, D., Gasiewski, A.J., Klein, M., Leuski, V.Y. (2008). Microwave and Millimeter-Wave Radiometric and Radiosonde Observations in an Arctic Environment. Journal of Atmospheric and Oceanic Technology, 25(10), 1768-1777. doi: 10.1175/2008jtecha1078.1

Mayangwulan, D., Wiratmo, J., Siregar, P.M.
(2011). Potensi Kejadian Badai Guntur Berdasarkan Parameter Kelembapan, Labilitas Udara dan Mekanisme Pengangkatan (Studi Kasus: Di Bandar Udara Frans Kaisiepo Biak). Jurnal Sains Dirgantara, 8(2), 139-156.

Meilani., Wahid, A., Bernandus. (2014). Analisa Data Radiosonde untuk Mengetahui Potensi Kejadian Badai Guntur di Bandar Udara El Tari Kupang. Prosiding Seminar Nasional Geofisika 2014, 159-163.

Novianti, D, Anjani, D., Ulfah. (2015). Analisis Indeks Kejadian Badai Guntur di Stasiun Meteorologi Cengkareng dengan Metode Rapid Miner dan Fuzzy Logic Guna Keselamatan Penerbangan. Semnasteknomedia Online, 3(1), 355-360.

Ratnam, M.V., Santhi, Y.D., Rajeevan, M., Rao, S.V.B. (2013). Diurnal Variability of Stability Indices Observed Using Radiosonde Observations over a Tropical Station: Comparison with Microwave Radiometer Measurements. Atmospheric Research, 124, 21-33. doi: 10.1016/J.Atmosres.2012.12.007

Tajbakhsh, S., Ghafarian, P., Sahraian, F. (2012). Instability Indices and Forecasting Thunderstorms: The Case of 30 April 2009. Natural Hazards Earth System Sciences, 12(2), 403-413.

Ilhamsyah, Y. (2012). Kajian Pendahuluan Analisis Peramalan Thunderstorm untuk Penyusunan Indeks Dasar Adaptasi Kegiatan Pertambakan (Suatu Tinjauan Meteorologi di Jakarta). Depik, 1(1), 53-60. 